\title{
Tokat Șartlarında Farklı Çerezlik Ayçiçeği (Helianthus annuus L.) Genotiplerinin Performanslarının Belirlenmesi
}

\author{
Güngör YILMAZ1', *Ahmet KINAY', Turan ER², Șaziye DÖKÜLEN \\ ${ }^{1}$ Gaziosmanpașa Üniversitesi, Ziraat Fakültesi, Tarla Bitkileri Bölümü, Tokat \\ ${ }^{2}$ Gaziosmanpașa Üniversitesi, Fen Bilimleri Enstitüsü, Tokat \\ *Sorumlu yazar e-posta (Corresponding author; e-mail): ahmet.kinay@gop.edu.tr \\ Geliș Tarihi (Received): 06.06.2017～Kabul Tarihi (Accepted): 06.07.2017
}

\begin{abstract}
Öz
Bu çalıșma Tokat-Kazova șartlarında bazı çerezlik ayçiçeği genotiplerinin verim ve kalite özelliklerinin belirlenmesi amacıyla 2014-2015 yıllarında yürütülmüștür. Araștırmada 20 farklı genotip (11-TRÇ-022, 10TRÇ-027, 09-TRÇ-004, Palancı-1, TTAE-ÇRZ-13-9, TTAE-ÇRZ-13-12, TTAE-ÇRZ-13-15, TTAE-ÇRZ-13-6, TTAE-ÇRZ-13-14, Aybak-2013-13-DAÇ130100, Aybak-2013-12-DAÇ13099, Aybak-2013-17-DAÇ130104, Aybak-2013-6-DAÇ13093, Aybak-2013-20-DAÇ130107, Aybak-2013-32-DAÇ130119, 703, 412, Baklan/ Denizli, Karakeçili/Kırıkkale ve İnegöl Alası) karșılaștııımıștır. Çalıșmada bitki boyu, yaprak sayısı, sap çapı, tabla çapı, tablada tohum sayısı, bin tane ağırlığı, tohum verimi, tane eni, tane boyu, kabuk oranı, iç oranı, hektolitre ağırlığı ve yağ oranı belirlenmiștir. İncelenen özelliklerden sap çapı ve yağ oranı hariç diğer parametreler genotiplere göre istatistiki olarak önemli bulunmuștur. Çalıșmanın iki yıllık sonucuna göre Aybak-2013-13-DAÇ130100 (529 kg/da), Baklan/Denizli (573 kg/da), Karakeçili/Kırıkkale (538kg/da) ve İnegöl Alası (545 kg/da) genotipleri tohum verimi bakımından istatistiki olarak ilk grupta yer almıșlardır. Baklan/Denizli popülasyonunun tüm özellikleri bakımından elverișli olması ve en yüksek tohum verimine sahip olmasından dolayı Tokat-Kazova șartlarında yetiștiriciliğinin yapılabileceği sonucuna varılmıștır.
\end{abstract}

Anahtar Kelimeler: Adaptasyon, çerezlik ayçiçeği, popülasyon, tohum verimi

\section{Determination of the Performance of Different Confectionery Sunflower (Helianthus annuus L.) Genotypes in Tokat Conditions}

\section{Abstract}

This research was carried out in years 2014 and 2015 to determine of the yield and quality properties of some confectionery sunflower genotypes in Tokat-Kazova conditions. Twenty genotypes (11-TRC -022, 10-TRC-027, 09-TRC-004, Palancı-1, TTAE-CRZ-13-9, TTAE-CRZ-13-12, TTAE-CRZ-13-15, TTAE-CRZ -13-6, TTAE-CRZ-13-14, Aybak-2013-13-DAC130100, Aybak-2013-12-DAC13099, Aybak-2013-17DAC130104, Aybak-2013-6-DAC13093, Aybak-2013-20-DAC130107, Aybak-2013-32-DAC130119, 703, 412, Baklan/Denizli, Karakeçili/Kırıkkale ve Inegöl Alası) were evaluated regarding their biomass production. Plant height, number of leaf, head diameter, stem diameter, achenes per head, 1000 achene weight, achene yield, grain size, grain length, shell ratio, kernel ratio, hectoliter weight and oil ratio were recorded. Significant differences among genotypes were found for all investigated traits except for stem diameter and oil ratio. The highest achene yields were obtained from Aybak-2013-13-DAC130100 (529 kg/da), Baklan/ Denizli (573 kg/da), Karakeçili/Kırıkkale (538 kg/da) and Inegöl Alası (545 kg/da) in the successive two years. According to the research results, Baklan/Denizli population is suitable for all its characteristics and has the highest seed yield. Therefore, it can be recommended for Tokat-Kazova conditions.

Keywords: Adaptation, confectionery sunflower, population, seed yield 


\section{Giriș}

Açiçeği, günümüzde büyük ölçüde yemeklik yağ gereksinimini karșılamak amacıyla kullanılmaktadır. Yağlık ayçiçeği üretiminin yanı sıra çerezlik ayçiçeği çeșitleri de üretimde yer almaktadır (Lofgren 1978). Gün geçtikçe tüketime bağlı olarak çerezlik ayçiçeğinin yetiștiriciliği de artmaktadır. Türkiye'de çerezlik ayçiçeği üretiminin arttırılması için yörelere uygun çeșitlere intiyaç bulunmaktadır.

Türkiye'de çerezlik ayçiçeği üretimi çoğunlukla popülasyon halinde yerel isimlerle anılan genotiplerle yapılmaktadır. Bunlardan bazıları, Alaca, Kırıkkale, Denizli, Kıbrıs, Maraș, Haymana alası, Aksaray gibi isimler verilen köy popülasyonları șeklindedir. 2008 yılından sonra Çiğdem 1, Palancı 1 isimli çeșitler de geliștirilmiș, ancak yaygın olarak üretimde yer bulamamıșlardır. Türkiye'de en yaygın olarak İnegöl Alası çeșidinin (2013 yılında tescil edilmiș) üretimi yapılmaktadır (Anonim 2014b).

Özgödek (1993), Türkiye'nin değișik yerlerinden temin edilen 13 çerezlik ayçiçeği ekotipinin Erzurum ekolojik șartlarına adaptasyonunu belirlemek amacıyla yaptığı çalıșmada, kullanılan ekotiplerin tane uzunlukları 14.1-28.0 mm tane genișlikleri 6.2-8.3 $\mathrm{mm}$ arasındadır. Hektolitre ağırığı 21.5-28.0 kg, 1000 tane ağırlığı 69.7-183.3 $\mathrm{g}$, tane iç oranları \%46.2-57.3 olarak tespit etmiștir. Aynı çalıșmada inceledikleri ekotiplerin tane verimlerini 218.4-354.9 kg/da arasında saptamıștır. Bir diğer çalıșmada ise Polatlı (2013), bazı çerezlik ayçiçeği (Helianthus annuus L.) popülasyonlarında verim ile agronomik özelliklerin belirlenmesi ve özellikler arasındaki ilișkilerin saptanması amacıyla 2011 vejetasyon döneminde bir çalıșma yapmıștır. Araștırma materyali olarak $\mathrm{F}_{3-4}$ kademesinde olan tekrarlamalı seleksiyonlarla geliștirilmiș dört çerezlik ileri popülasyondan rastgele seçilmiș 20'șer bitki kullanılmıștır. Uzun bitki boyu, geniș tabla çapı, tane eni-boyu büyük, tek bitki verimi, yağ oranı ve düșük kabuk oranı ile popülasyon4'ün ön plana çıktığını bildirmiștir.

Çerezlik ayçiçeği tüketiminin gün geçtikçe artmasıyla olușan talep, ithalatı arttırmakta ve buna bağlı olarak da yurt içi üretim daha da önem kazanmaktadır. Bu yüzden çerezlik ayçiçeğiyle ilgili araștırmalara hız verilmesi gerekliliği ortaya çıkmaktadır. Halen 31 ilde üretimi yapılan çerezlik ayçiçeğinin Tokat ve yöresinde de üretilebileceği düșünülmektedir. Ancak, Tokat yöresinde daha çok yağlık ayçiçeği üretilmektedir. Çerezlik amaçıı üretime Turhal yöresinde henüz yeni bașlanmıș olup, istatistiklere yansıyacak düzeyde üretiminin yapılmadığı anlașılmaktadır (Anonim 2014a). Genellikle çerezlik ayçiçeği çeșitlerinin verimleri, yağlık ayçiçeği çeșitlerine göre daha düșük olduğu bildirilmektedir (Kaya 2004). Nitekim 2013 yılı itibariyle yağlık ayçiçeğinin dekara verimi 265 kg iken, çerezlik ayçiçeğinden 160 kg kadar verim alınabilmiștir (Anonim 2014a). Ayrıca, Türkiye'nin değișik yerlerinde üretilen çerezlik genotiplerin, Tokat'taki performanslarının ne olacağına dair bu güne kadar bir çalıșma da yapılmamıștır.

$\mathrm{Bu}$ araștırma ile Tokat șartlarında farklı çerezlik ayçiçeği genotipleri ile ilk defa bir çalıșma yapılmıștır. Bu çalıșmada yer alan genotiplerden ikisi tescilli çeșit, 18'i ise yerel isimlerle anılan genotiplerdir. $\mathrm{Bu}$ genotiplerin Tokat șartlarındaki performanslarının belirlenmesi ile Tokat'ta çerezlik ayçiçeği tarımının ne ölçüde ekonomik olacağına ıșık tutulmuș, ayrıca mevcut varyasyonun bundan sonraki çalıșmalarda nasıl değerlendirilebileceğine dair de bilgiler verilmiștir.

\section{Materyal ve Yöntem}

Araștırma, 2014-2015 yılları vejetasyon dönemlerinde Gaziosmanpașa Üniversitesi, Tarımsal Uygulama ve Araștırma Merkezi deneme alanlarında yürütülmüștür. Araștırmada materyal olarak, Trakya Tarımsal Araștırma Enstitüsü (11-TRÇ-022, 10-TRÇ027, 09-TRÇ-004, Palancı-1, TTAE-ÇRZ-13-9, TTAE-ÇRZ-13-12, TTAE-ÇRZ-13-15, TTAEÇRZ-13-6 ve TTAE-ÇRZ-13-14), Doğu Akdeniz Tarımsal Araștırma Enstitüsü (Aybak-201313-DAÇ130100, Aybak-2013-12-DAÇ13099, Aybak-2013-17-DAÇ130104, Aybak-20136-DAÇ13093, Aybak-2013-20-DAÇ130107, Aybak-2013-32-DAÇ130119, 703 ve 412) ve farklı yerlerdeki üreticilerden (Baklan/Denizli, Karakeçili/Kırıkkale ve İnegöl Alası) temin edilen toplam 20 adet çerezlik çeșit, hat ve 
Çizelge 1. Çalıșmaların yürütüldüğü alanın vejetasyon dönemine ait iklim verileri

Table 1. Climate data for the vegetation period of the area where the studies are carried out

\begin{tabular}{lcccccc}
\hline & Yıllar & Nisan & Mayıs & Haziran & Temmuz & Ağustos \\
\hline Ortalama sıcaklık $\left({ }^{\circ} \mathrm{C}\right)$ & $1983-2013$ & 12.5 & 16.2 & 19.6 & 22.1 & 22.3 \\
& 2014 & 15.0 & 17.3 & 20.4 & 23.3 & 25.4 \\
& 2015 & 10.0 & 16.9 & 20.0 & 23.5 & 24.3 \\
Ortalama nem (\%) & $1983-2013$ & 58.0 & 60.4 & 58.3 & 56.4 & 57.5 \\
& 2014 & 41.2 & 51.2 & 54.5 & 46.8 & 42.0 \\
Toplam Yağıș (mm) & 2015 & 57.6 & 57.1 & 63.6 & 52.4 & 54.5 \\
& $1983-2013$ & 57.2 & 62.9 & 37.9 & 12.8 & 6.1 \\
& 2014 & 15.6 & 10.8 & 56.4 & 0.6 & 1.1 \\
& 2015 & 29.1 & 34.8 & 35.4 & 0.2 & 7.6 \\
\hline
\end{tabular}

Tokat Meteoroloji Müdürlüğü

Tokat Meteorology Directorate

Çizelge 2. Araștırma alanına ait toprak analiz sonuçları

Table 2. Soil analysis results of the research area

\begin{tabular}{cccccccc}
\hline Yıllar & Tekstür & $\begin{array}{c}\text { Toplam } \\
\text { tuz }(\%)\end{array}$ & $\mathrm{pH}(\%)$ & $\begin{array}{c}\text { Kireç }\left(\mathrm{CaCO}_{3}\right) \\
(\%)\end{array}$ & $\begin{array}{c}\text { Fosfor } \\
\left(\mathrm{P}_{2} \mathrm{O}_{5}\right)\end{array}$ & $\begin{array}{c}\text { Potasyum } \\
\left(\mathrm{K}_{2} \mathrm{O}\right)\end{array}$ & $\begin{array}{c}\text { Organik } \\
\text { Madde }(\%)\end{array}$ \\
\hline 2014 & Tınlı & 0.017 & 7.77 & 11.57 & 6.3 & 38.61 & 0.48 \\
2015 & Tınlı & 0.023 & 7.61 & 13.53 & 6.72 & 48.93 & 1.23 \\
\hline
\end{tabular}

popülasyon kullanılmıștır. Bunlardan Palancı-I ile İnegöl Alası tescilli çeșitler olup diğerleri hat ve popülasyon seviyesindedir.

Araștırmanın yürütüldüğü Tokat İli, coğrafi olarak Karadeniz Bölgesinde olmasına rağmen Orta Anadolu ile Karadeniz iklimi arasında geçit kușağı iklim özelliği göstermektedir. Çalıșmanın yürütüldüğü alanların aylık yağıș toplamları karșılaștırılığında, uzun yıllara göre bir azalma, ancak 2014 yılı Haziran ayında artıș olduğu görülmüștür. Sıcaklıklarda çok büyük değișiklikler olmamasına rağmen uzun yıllara göre bir artıș belirlenmiștir. Sıcaklık artıșı ve yağıșların azalmasına bağlı olarak da, ortalama nem değerlerinde uzun yıllara göre düșüșler gerçekleșmiștir.

Çalıșmaların yürütüldüğü alanların toprak özellikleri tınlı, tuzsuz, hafif alkali ve organik madde bakımından fakir bir toprak özelliğine sahiptir (Karaman ve Brohi 2004).

Araștırma, Tesadüf Blokları Deneme Desenine göre üç tekerrürlü olarak yürütülmüștür. Ekim ișlemi, markörle açllan sıralara el ile ekim sıklığı 70x40 cm (Akkaya 2006) olacak șekilde 2 Nisan 2014 ve 15 Nisan 2015 tarihlerinde yapılmıștır.

Denemelerde parseller ikișer sıradan ibarettir. Her bir genotipe ait sıralar ara verilmeksizin birbirini takip eder biçimde düzenlenmiștir. Parsellerde sıraların uzunluğu $6 \mathrm{~m}$ olup, her sıraya, bașlangıçta $40 \mathrm{~cm}$ aralıklarla 30 adet tohum (her $40 \mathrm{~cm}$ 'ye iki tohum) ekilmiștir. Çıkıștan sonra her 40 cm'de tek bitki olacak șekilde tekleme yapılmıștır. Blokların baș ve sonlarından birer sıra kenar etkisi olușturulmuștur. Denemede $\mathrm{P}$ ve K'un tamamı ekim esnasında $7 \mathrm{~kg} / \mathrm{da}, \mathrm{N}$ ise $15 \mathrm{~kg} /$ da șeklinde yarısı ekimle birlikte NPK (15-1515) formunda, diğer yarısı ise bitkiler yaklașık $30 \mathrm{~cm}$ boya ulaștı̆ı̆ında amonyum nitrat formunda uygulanmıștır (Zubillaga et al. 2002).

Ekimsonrasıbitkigelișimleritamamlanıncaya kadar yabancı otlarla mücadele edilmiștir. Sulama ișlemi, kritik gelișme dönemi olan tabla olușum bașlangıcından itibaren topraktaki 
nemin durumuna göre intiyaç belirdiğinde yüzeyden damla sulama yöntemi ile yapılmıștır.

Hasatta parsellerin baș ve sonlarından ikișer bitki kenar etkisi olarak değerlendirme dıșı tutulmuștur. Hasat, brakte yaprakların yarıya yakın kısmının sarıdan kahverengine dönüștüğü ve tablanın arka kısmında \%110 kahverengileșme olușmaya bașladığı 29 Ağustos 2014 ve 25 Ağustos 2015 tarihinde tablalar kesilerek hasat edilmiștir. Hasat sonrası tam kuruması tamamlanan tablalar harman edilmiștir. Harman sonrasında nem oranları \%8'e sabitlenerek dekara tohum verimleri hesaplanmıș ve her bir parselden ayrı ayrı örnekler alınarak yağ analizleri yapılmıștır. Araștırma sonucunda elde edilen veriler Tesadüf Blokları Deneme Desenine göre varyans analizine tabi tutulmuș ve ortalamalar arasındaki farklılıkların Duncan çoklu karșılaștırma testiyle belirlenmiștir (Düzgünes ve ark. 1987).

\section{Bulgular ve Tartıșma}

Araștırmada incelenen çerezlik ayçiçeği genotiplerinin bitki boyları $128 \mathrm{~cm}$ (11-TRÇ -022) ile $221 \mathrm{~cm}$ (Aybak-2013-12-DAÇ13099) arasında değișmiștir. Çalıșmada yer alan 11 hattın, ortalamanın $(175 \mathrm{~cm})$ üzerinde bitki boyuna sahip olduğu belirlenmiștir. Yaprak sayısı 15.9 (TTAE-ÇRZ-13-9) ile 25.4 (Aybak2013-12-DAÇ 13099) adet/bitki arasında değișmiștir. Yapraklar fotosentez etkinliği açısından önemli organlar olduğundan, kuru madde üretimi ve ürün olușumunda fonksiyoneldirler. Araștırmada bitki boyu artıșına bağlı olarak yaprak sayısının da arttığı ve bunun diğer verim öğelerine olumlu etkisinin olduğu belirlenmiștir.

Araștırmada incelenen çerezlik ayçiçeği genotiplerinin ortalama sap çapları 26.5-33.1 $\mathrm{mm}$ arasında değișirken, en kalın sapa Aybak2013-13-DAÇ 130100 hattının sahip olduğu

Çizelge 3. Çerezlik ayçiçeği genotiplerin yaprak sayısı, bitki boyu ve sap çapı değerleri

Table 3. Number of leaves, plant height and stem diameter of the confectionery sunflower genotypes

\begin{tabular}{|c|c|c|c|c|c|c|c|c|c|c|c|c|}
\hline \multirow{3}{*}{$\begin{array}{l}\text { No } \\
1\end{array}$} & \multirow{3}{*}{$\begin{array}{l}\text { Hatlar/Çeșitler/ Popülasyonlar } \\
11 \text { Trç } 022\end{array}$} & \multicolumn{4}{|c|}{ Bitki boyu $(\mathrm{cm})^{\star}$} & \multicolumn{4}{|c|}{ Yaprak sayısı (adet) ${ }^{*}$} & \multicolumn{3}{|c|}{ Sap çapı $(\mathrm{mm})^{\text {ÖD }}$} \\
\hline & & \multirow{2}{*}{$\begin{array}{c}2014 \\
124\end{array}$} & \multirow{2}{*}{$\frac{2015}{132}$} & \multicolumn{2}{|c|}{ Ort. } & \multirow{2}{*}{$\frac{2014}{17.8}$} & \multirow{2}{*}{$\begin{array}{c}2015 \\
15.8\end{array}$} & \multicolumn{2}{|c|}{ Ort. } & \multirow{2}{*}{$\frac{2014}{24.4}$} & \multirow{2}{*}{$\begin{array}{r}2015 \\
28.9\end{array}$} & \multirow{2}{*}{$\begin{array}{l}\text { Ort. } \\
26.6\end{array}$} \\
\hline & & & & 128 & $\mathrm{~h}$ & & & 16.8 & def & & & \\
\hline 2 & $10 \operatorname{Trç~} 027$ & 130 & 133 & 132 & gh & 16.1 & 16.4 & 16.3 & ef & 24.2 & 28.7 & 26.5 \\
\hline 3 & 09 Trç 004 & 159 & 160 & 159 & $d-h$ & 17.1 & 21.2 & 19.1 & $b-f$ & 26.3 & 30.2 & 28.2 \\
\hline 4 & Palancı & 141 & 160 & 150 & e-h & 15.0 & 19.3 & 17.2 & def & 25.4 & 30.5 & 28.0 \\
\hline 5 & Ttae-Çrz-13-9 & 148 & 140 & 144 & fgh & 15.1 & 16.6 & 15.9 & $f$ & 25.4 & 30.2 & 27.8 \\
\hline 6 & Ttae-Çrz-13-12 & 144 & 184 & 164 & $c-f$ & 20.3 & 22.8 & 21.5 & $a-e$ & 27.6 & 32.6 & 30.1 \\
\hline 7 & Ttae-Çrz-13-15 & 160 & 170 & 165 & $c-f$ & 19.2 & 23.4 & 21.3 & $a-e$ & 26.9 & 29.9 & 28.4 \\
\hline 8 & Ttae-Çrz-13-6 & 145 & 164 & 154 & e-h & 17.9 & 20.1 & 19.0 & $b-f$ & 26.8 & 29.4 & 28.1 \\
\hline 9 & Ttae-Çrz-13-14 & 161 & 147 & 154 & e-h & 16.5 & 19.4 & 18.0 & $c-f$ & 24.5 & 27.8 & 26.1 \\
\hline 10 & Aybak-2013-13-Daç130100 & 184 & 217 & 201 & $a b$ & 22.2 & 25.1 & 23.6 & $a b$ & 31.4 & 34.8 & 33.1 \\
\hline 11 & Aybak-2013-12-Daç13099 & 210 & 232 & 221 & a & 23.0 & 27.8 & 25.4 & a & 28.3 & 34.2 & 31.3 \\
\hline 12 & Aybak-2013-17-Daç130104 & 194 & 214 & 204 & $a b$ & 23.1 & 25.8 & 24.5 & $a b$ & 28.2 & 33.7 & 31.0 \\
\hline 13 & Aybak-2013-6-Daç13093 & 185 & 209 & 197 & $a b$ & 20.3 & 23.2 & 21.8 & $a-d$ & 28.2 & 30.9 & 29.6 \\
\hline 14 & Aybak-2013-20-Daç130107 & 187 & 194 & 191 & $\mathrm{bc}$ & 20.8 & 25.6 & 23.2 & $a b c$ & 26.8 & 29.6 & 28.2 \\
\hline 15 & Aybak-2013-32-Daç130119 & 189 & 201 & 195 & $a b$ & 22.2 & 25.3 & 23.8 & $a b$ & 26.0 & 33.1 & 29.6 \\
\hline 16 & 703 & 175 & 193 & 184 & bcd & 21.6 & 26.2 & 23.9 & $a b$ & 25.0 & 29.0 & 27.0 \\
\hline 17 & 412 & 190 & 203 & 197 & $a b$ & 20.9 & 24.8 & 22.9 & $a b c$ & 24.5 & 29.1 & 26.8 \\
\hline 18 & Baklan/Denizli & 175 & 199 & 187 & bcd & 21.5 & 26.2 & 23.8 & $a b$ & 27.3 & 32.8 & 30.0 \\
\hline 19 & Karakeçili/Kırıkkale & 187 & 205 & 196 & $a b$ & 19.5 & 24.4 & 22.0 & $a-d$ & 27.9 & 34.5 & 31.2 \\
\hline 20 & İnegöl alası & 170 & 188 & 179 & $b-e$ & 20.0 & 24.1 & 22.1 & $a-d$ & 26.2 & 30.6 & 28.4 \\
\hline \multicolumn{2}{|c|}{ Ortalama } & 168 & 182 & 175 & & 20 & 23 & 21 & & 27 & 31 & 29 \\
\hline \multicolumn{2}{|c|}{$\%$ VK } & & & & 11.2 & & & & 14,3 & & & 14,6 \\
\hline
\end{tabular}


belirlenmiștir. Genotiplerin yapısal özelliklerine bağlı olarak sap kalınlıkları değișmektedir (Knowles 1978; Majid and Schnettier 1988; Karakaș 2012). Sap kalınlığı, rüzgar gibi dıș etkenlere karșı bitkinin dayanma gücünü arttıran önemli bir özellik olup, çevre koșullarından oldukça etkilenmektedir. Çerezlik ayçiçeğinde sap çapının fazla olması yatma veya gövdelerde kırıma olmamasının yanında iletim sisteminin de etkin çalıșmasını sağlamaktadır.

Ayçiçeği çalıșmalarında tabla çapı, tablada tane sayısı ve bin tane ağırlığı verimi doğrudan etkileyen parametreler arasında öne çıkan özelliklerdir. Bu çalıșmada en büyük tabla çapı 22.6 cm ile Aybak-2013-32-DAÇ 130119 hattı olurken, tablada tane sayısı bakımından ise dört hat/çeșit (İnegöl alası, Aybak-20136-DAÇ 13093, 412 ve Aybak-2013-13-DAÇ 130100) en yüksek değere sahip olmuș ve aynı istatistiki grupta yer almıștır.
Bin tane ağırlığı bakımından 11-TRÇ -022 hattı ve İnegöl alası çeșidi en yüksek değerlere sahip olmuștur. Tohum verimi bakımından en yüksek değere Baklan-Denizli $(573$ kg/ da) popülasyonunun sahip olduğu tespit edilmiștir. Tabla çapı ve tablada tane sayısı bakımından istatistiki olarak ilk grupta yer alan bu popülasyonun verimi de en yüksek olmuștur. Tohum verimi bakımından BaklanDenizli popülasyonunu sırasıyla İnegöl alası çeșidi, Karakeçili-Kırıkkale popülasyonu ve Aybak-2013-13-DAÇ 130100 hattı takip etmiș ve istatistiki olarak aynı grupta yer almıștır.

Yağlık ayçiçeğinde olduğu gibi çerezlik ayçiçeğinde de bitkinin ticari değerini dekara tane verimi belirler. $\mathrm{Bu}$ nedenle, birim alandaki tane verimi birinci derecede önemli bir karakterdir. Öte yandan tane verimi son derecede kompleks bir karakter olup, genotipten, çevre koșullarından ve yetiștirme

Çizelge 4. Çerezlik ayçiçeği genotiplerinin tabla çapı, tablada tane sayısı ve bin tane ağırlı̆̆ değerleri Table 4. Table diameter, achenes per head and 1000 achene weight of the confectionery sunflower genotypes

\begin{tabular}{|c|c|c|c|c|c|c|c|c|c|c|c|c|}
\hline \multirow{3}{*}{$\begin{array}{l}\text { No } \\
1\end{array}$} & \multirow{3}{*}{$\begin{array}{l}\text { Hatlar/Çeșitler/ } \\
\text { Popülasyonlar } \\
11 \text { Trç } 022\end{array}$} & \multicolumn{3}{|c|}{ Tabla çapı $(\mathrm{cm})^{\star}$} & \multicolumn{4}{|c|}{ Tablada tane sayısı (adet)* } & \multicolumn{4}{|c|}{ Bin tane ağırlığı $(g)^{*}$} \\
\hline & & \multirow{2}{*}{$\begin{array}{r}2014 \\
17.6\end{array}$} & \multirow{2}{*}{\begin{tabular}{|c|}
2015 \\
19.1
\end{tabular}} & \multirow{2}{*}{$\frac{\text { Ort. }}{18.3 \mathrm{de}}$} & \multirow{2}{*}{$\begin{array}{c}2014 \\
685\end{array}$} & \multirow{2}{*}{$\frac{2015}{661}$} & \multicolumn{2}{|c|}{ Ort. } & \multirow{2}{*}{$\begin{array}{c}2014 \\
179\end{array}$} & \multirow{2}{*}{$\begin{array}{c}2015 \\
160\end{array}$} & \multicolumn{2}{|c|}{ Ort. } \\
\hline & & & & & & & 673 & $d$ & & & 169 & $\mathrm{a}$ \\
\hline 2 & $10 \operatorname{Trç~} 027$ & 16.8 & 21.9 & 19.4 a-e & 598 & 754 & 676 & $d$ & 176 & 155 & 165 & $a b$ \\
\hline 3 & 09 Trç 004 & 18.1 & 21.3 & 19.7 a-e & 729 & 879 & 804 & bcd & 157 & 155 & 156 & $a-e$ \\
\hline 4 & Palancı & 16.7 & 23.6 & 20.2 a-e & 605 & 697 & 651 & $d$ & 173 & 153 & 163 & $a b c$ \\
\hline 5 & Ttae-Çrz-13-9 & 16.6 & 19.4 & $18.0 \mathrm{e}$ & 716 & 774 & 745 & $\mathrm{~cd}$ & 169 & 150 & 159 & $a-d$ \\
\hline 6 & Ttae-Çrz-13-12 & 19.0 & 23.4 & 21.2 a-e & 977 & 1139 & 1058 & $a b$ & 162 & 148 & 155 & a-e \\
\hline 7 & Ttae-Çrz-13-15 & 16.7 & 21.5 & $19.1 \mathrm{~b}-\mathrm{e}$ & 933 & 985 & 959 & $a b c$ & 162 & 123 & 143 & $d-g$ \\
\hline 8 & Ttae-Çrz-13-6 & 18.0 & 22.6 & 20.3 a-e & 733 & 916 & 824 & bcd & 142 & 122 & 132 & $\mathrm{fg}$ \\
\hline 9 & Ttae-Çrz-13-14 & 17.1 & 20.2 & 18.7 cde & 814 & 837 & 825 & bcd & 149 & 124 & 136 & efg \\
\hline 10 & Aybak-2013-13-Daç130100 & 20.9 & 23.9 & $22.4 a b$ & 1096 & 1242 & 1169 & a & 161 & 145 & 153 & $a-e$ \\
\hline 11 & Aybak-2013-12-Daç13099 & 22.2 & 21.9 & $22.0 \mathrm{abc}$ & 1184 & 989 & 1087 & $a b$ & 133 & 127 & 130 & $g$ \\
\hline 12 & Aybak-2013-17-Daç130104 & 19.9 & 20.4 & 20.2 a-e & 880 & 1086 & 983 & $a b c$ & 155 & 135 & 145 & $c-g$ \\
\hline 13 & Aybak-2013-6-Daç13093 & 20.7 & 22.7 & 21.7 a-d & 1051 & 1174 & 1112 & a & 158 & 133 & 146 & $d-g$ \\
\hline 14 & Aybak-2013-20-Daç130107 & 20.3 & 23.4 & $21.8 \mathrm{abc}$ & 856 & 1186 & 1021 & $a b$ & 160 & 145 & 152 & $a-e$ \\
\hline 15 & Aybak-2013-32-Daç130119 & 21.1 & 24.0 & $22.6 \mathrm{a}$ & 930 & 1172 & 1051 & $a b$ & 152 & 155 & 154 & $a-e$ \\
\hline 16 & 703 & 20.2 & 22.2 & 21.2 a-e & 963 & 1115 & 1039 & $a b$ & 167 & 148 & 157 & $a-d$ \\
\hline 17 & 412 & 19.7 & 22.6 & 21.1 a-e & 1104 & 1202 & 1153 & a & 151 & 140 & 146 & $c-g$ \\
\hline 18 & Baklan/Denizli & 21.4 & 23.5 & $22.4 a b$ & 1039 & 1113 & 1076 & $a b$ & 148 & 151 & 150 & $b-f$ \\
\hline 19 & Karakeçili/Kırıkkale & 20.0 & 23.2 & 21.6 a-d & 1007 & 1123 & 1065 & $a b$ & 158 & 148 & 153 & $a-e$ \\
\hline 20 & İnegöl alası & 20.3 & 23.4 & $21.8 \mathrm{abc}$ & 1065 & 1183 & 1124 & a & 182 & 154 & 168 & a \\
\hline \multicolumn{2}{|c|}{ Ortalama } & 19 & 22 & 21 & 898 & 1011 & 955 & & 160 & 144 & 152 & \\
\hline \multicolumn{2}{|c|}{$\% \mathrm{VK}$} & & & 11.4 & & & & 15.9 & & & & 9.2 \\
\hline
\end{tabular}

${ }^{*}: 0.05$ seviyesinde istatistiki olarak önemli, VK: Varyasyon katsayısı

Significant at the level of 0.05, VK: Coefficient of variation 
tekniği uygulamalarından önemli derecede etkilenmektedir (Çil ve ark. 2011). Çerezlik ayçiçeğinde kullanılan popülasyon niteliğindeki genotiplerin veriminin stabil olmadığı Akkaya (2006) tarafından belirtilmiștir. Ayçiçeğinde tohum verimi ile birim alandaki tabla sayısı, tabla çapı, tablada tohum sayısı ve bin tane ağırlığı arasında doğrusal bir ilișkinin olduğu Turan ve Göksoy (1998), tarafından bildirilmiștir. Bu özelliklerin olușumunda bitki sıklığı ile agronomik uygulamaların etkinliği belirleyici rol oynamaktadır. Nitekim, Kaya ve ark. (2006), özellikle tane dolum döneminde yapılan sulamanın dekara tane verimini arttırdığını bildirmiștir. Tabla çapı, bin tane ağırlığı ve bitkide tane verimi, bitki sıklığının artmasıyla dekara tane veriminin arttığı Day (2011) tarafından da bildirilmiștir. Ayrıca tane veriminin genotiplere göre varyasyon göstermesigenotiplerinverimi belirleyen kalıtsal özelliklerinin farklılı̆ından kaynaklanmaktadır (Sbabana 1974; Fick et al. 1974; Pathak 1974; Katar ve ark. 2012). Bu çalıșmada, bin tane ağırı̆̆ı, tabla çapı, tablada tane sayısı gibi özellikler bakımından yüksek değerlere sahip genotiplerin tohum verimlerinin de genellikle yüksek olduğu görülmüștür (Çizelge 6).

Araștırmada kullanılan çerezlik ayçiçeği genotiplerinin ortalama tane boyları 19.2-23.9 $\mathrm{mm}$, tane eni ise 6.9-8.1 mm arasında değișim göstermiștir. Çalıșmamızda, genotiplerin ortalama tane boyu değerleri Lofgren (1978)'in bildirdiği çerezlik çeșitlerde olması gereken en düșük2.5cmuzunluğunaltındagerçekleșmiștir. Ancak çalıșmada, bu değere yakın tane boyuna sahip genotipler de bulunmaktadır. Tane boyu bakımından genotipler arasında görülen fark çeșit özelliğinden (Fick 1978; Knowles 1978; Öztürk ve ark. 2008) kaynaklanmıștır. Tane boyu bir çeșit özelliği olmasına rağmen, tabla

Çizelge 5. Çerezlik ayçiçeği genotiplerin tane eni, tane boyu ve hektolitre ağırlığı değerleri* Table 5. Grain size, grain length and hectoliter weight of confectionery sunflower genotypes

\begin{tabular}{|c|c|c|c|c|c|c|c|c|c|c|c|c|c|}
\hline \multirow{2}{*}{ No } & \multirow{2}{*}{$\begin{array}{l}\text { Hatlar/Çeșitler/ } \\
\text { Popülasyonlar }\end{array}$} & \multicolumn{4}{|c|}{ Tane eni $(\mathrm{cm})^{*}$} & \multicolumn{4}{|c|}{ Tane boyu $(\mathrm{cm})^{*}$} & \multicolumn{4}{|c|}{ Hektolitre ağırlığı $(g)^{*}$} \\
\hline & & 2014 & 2015 & & rt. & 2014 & 2015 & Ort & & 2014 & 2015 & Or & rt. \\
\hline 1 & 11 Trç 022 & 8.0 & 7.5 & 7.8 & $a-d$ & 21.7 & 21.7 & 21.7 & $\mathrm{~cd}$ & 241 & 241 & 241 & e-h \\
\hline 2 & 10 Trç 027 & 7.7 & 7.4 & 7.6 & $a-e$ & 21.3 & 21.4 & 21.3 & de & 250 & 258 & 254 & $b-g$ \\
\hline 3 & 09 Trç 004 & 8.1 & 7.7 & 7.9 & $a b c$ & 19.9 & 20.9 & 20.4 & def & 259 & 268 & 264 & $a-e$ \\
\hline 4 & Palancı & 8.5 & 6.7 & 7.6 & $a-e$ & 19.0 & 19.7 & 19.3 & fg & 284 & 283 & 283 & $\mathrm{a}$ \\
\hline 5 & Ttae-Çrz-13-9 & 8.1 & 7.4 & 7.7 & $a-e$ & 21.3 & 20.6 & 20.9 & de & 260 & 260 & 260 & $a-e$ \\
\hline 6 & Ttae-Çrz-13-12 & 7.5 & 6.8 & 7.2 & $b-e$ & 19.6 & 18.7 & 19.2 & g & 223 & 262 & 242 & e-h \\
\hline 7 & Ttae-Çrz-13-15 & 7.4 & 6.7 & 7.0 & de & 21.6 & 21.1 & 21.3 & de & 289 & 252 & 271 & $a-d$ \\
\hline 8 & Ttae-Çrz-13-6 & 7.1 & 6.7 & 6.9 & e & 20.5 & 19.7 & 20.1 & efg & 278 & 282 & 280 & $a b$ \\
\hline 9 & Ttae-Çrz-13-14 & 7.3 & 6.9 & 7.1 & cde & 20.1 & 20.1 & 20.1 & efg & 286 & 266 & 276 & $a b c$ \\
\hline 10 & Aybak-2013-13-Daç130100 & 8.2 & 7.0 & 7.6 & $a-e$ & 25.0 & 22.9 & 23.9 & a & 229 & 232 & 231 & fgh \\
\hline 11 & Aybak-2013-12-Daç13099 & 8.0 & 7.5 & 7.8 & $a-d$ & 20.6 & 21.4 & 21.0 & de & 246 & 263 & 254 & $b-g$ \\
\hline 12 & Aybak-2013-17-Daç130104 & 7.7 & 7.2 & 7.4 & $a-e$ & 23.0 & 22.2 & 22.6 & bc & 230 & 251 & 240 & e-h \\
\hline 13 & Aybak-2013-6-Daç13093 & 8.1 & 7.5 & 7.8 & $a-d$ & 21.6 & 20.6 & 21.1 & de & 238 & 243 & 240 & e-h \\
\hline 14 & Aybak-2013-20-Daç130107 & 8.8 & 7.3 & 8.0 & $\mathrm{~b}$ & 20.7 & 20.6 & 20.6 & de & 229 & 274 & 251 & $\mathrm{c}-\mathrm{h}$ \\
\hline 15 & Aybak-2013-32-Daç130119 & 8.3 & 7.9 & 8.1 & a & 23.9 & 22.8 & 23.3 & $a b$ & 217 & 241 & 229 & gh \\
\hline 16 & 703 & 8.1 & 7.8 & 8.0 & $b$ & 24.3 & 22.0 & 23.1 & $a b$ & 250 & 265 & 258 & $b-f$ \\
\hline 17 & 412 & 7.9 & 7.4 & 7.6 & $a-e$ & 24.1 & 23.2 & 23.6 & $a b$ & 212 & 238 & 225 & $\mathrm{~h}$ \\
\hline 18 & Baklan/Denizli & 7.8 & 7.7 & 7.7 & a-e & 22.3 & 23.8 & 23.1 & $a b$ & 250 & 255 & 252 & $c-g$ \\
\hline 19 & Karakeçili/Kırıkkale & 8.3 & 7.0 & 7.7 & $a-e$ & 23.9 & 21.3 & 22.6 & bc & 243 & 248 & 246 & $d-h$ \\
\hline 20 & İnegöl alası & 8.7 & 7.5 & 8.1 & a & 23.8 & 22.3 & 23.0 & $a b$ & 224 & 234 & 229 & gh \\
\hline \multicolumn{2}{|c|}{ Ortalama } & 8.0 & 7.3 & 7.6 & & 21.9 & 21.3 & 21.6 & & 247 & 256 & 251 & \\
\hline \multicolumn{2}{|c|}{$\% \mathrm{VK}$} & & & & 7.4 & & & & 4.2 & & & & 7.5 \\
\hline
\end{tabular}

*:0.05 seviyesinde istatistiki olarak önemli, VK: Varyasyon katsayısı

Significant at the level of 0.05, ÖD: Non-significan, VK: Coefficient of variation 


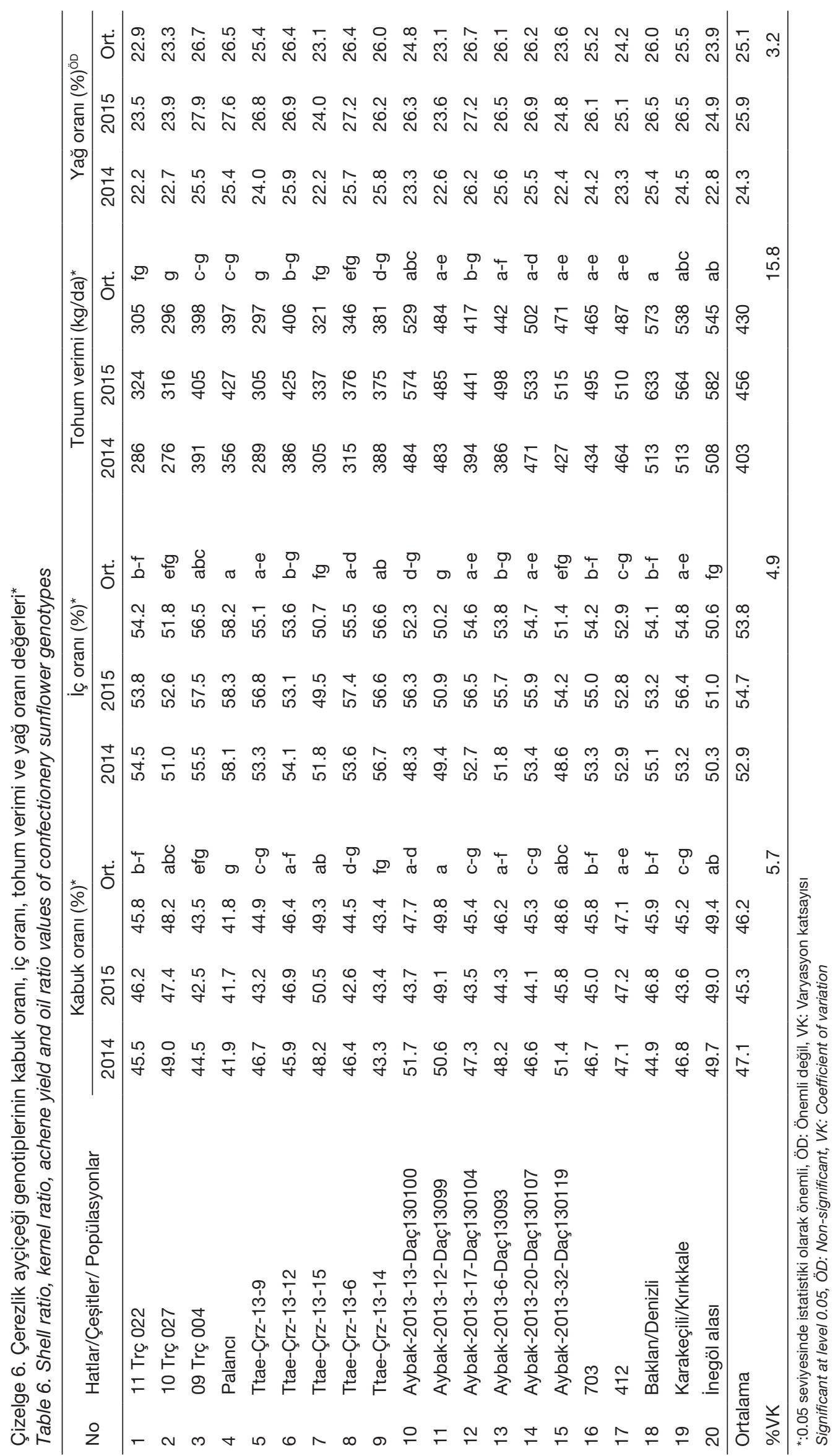


çapı, tabladaki tane sayısı ve bin tane ağırlığı ile yakından ilișkilidir (Ekin 2005). Çerezlik ayçiçeğinde tane boyunun artıșıyla tane dolgunluğu veya iç oranının da yüksek olması istenmektedir. Aksi takdirde aken tipi bir meyve yapısına sahip olan çerezlik ayçiçeği tanelerinin tek bașına boyca uzun olmaları tercih edilmeleri için yeterli olmamaktadır.

Hektolitre ağırlığı ise 22.48-28.34 kg arasında değișim göstermiștir. Çerezliklerin yağlıklara göre tanelerinin daha iri ve iç oranlarının düșük olmasından dolayı, yağlıklara göre hektolitre ağırlıkları düșük olmaktadır (Karadoğan ve Özgödek 1994; Tursun 2011).

$\mathrm{Bu}$ çalıșmada en yüksek iç oranına sahip genotip Palancı-1 (\%58.2) olup bunu sırasıyla TTAE-ÇRZ-13-14 (56.6) ve 09-TRÇ-004 (56.5) hatları izlemiștir. Çerezlik olarak kullanılan çeșitlerin tanelerinde iç oranının en az \%50 olması gerektiği vurgulanmıștır (Lofgren 1978). Genotiplerden elde edilen ortalama iç oranları belirlenen sınırlar içerisinde yer almıștır. Ayçiçeğinde kabuk oranı, tanelerin dolum oranına bağlıdır. Tane dolum sürecinde yüksek sıcaklık ve düzenli sulama ile birlikte bitkilerin sudan yararlanma oranları artmıș ve topraktan daha fazla bitki besin elementi alınarak etkili bir fotosentez sağlanmıștır. Etkili fotosentez sonucunda kuru madde ve besin maddeleri birikimi artmıș ve tane dolum oranları da yükselmiștir. Dolayısıyla tanelerin iç oranları yüksek, kabuk oranları daha düșük olmuștur.

Araștırmada yağ oranları \%22.9-\%26.7 arasında değișim göstermiștir. Genotipler arasındaki yağ oranları farklılıkları istatistiki olarak önemli bulunmamıștır. Çerezlik ayçiçeğinde, yağlık ayçiçeğinden farklı olarak yağ oranının yüksek olması arzu edilen bir durum değildir. Yağ oranı pek çok çevresel faktörden etkilenen bir karakterdir. Akkaya (2006), çerezlik ayçiçeğinde ekim zamanı ve bitki sıklığının verim ve kalite üzerine etkilerini araștırdığı çalıșmasında, Nisan ayı ekimlerinde ve65X15 bitkisıklığındaenyüksekyağ oranlarını elde ettiğini bildirmiștir. Yağ oranı üzerine birçok unsur etki etmekle beraber, genotipler arasında görülen farklılık büyük ölçüde genetik yapıdan (Fick 1978) kaynaklanmaktadır. Gundaev (1971), yağ oranının kabuk-iç oranına bağlı, yağ oranındaki artıșın kabuk oranındaki azalmaya bağlı olduğunu araștırmalarla ortaya koymuștur. Nitekim araștırmamızda en düșük kabuk oranına sahip olan 09-TRÇ-004, Palancı-1, TTAE-ÇRZ-13-14 ve Baklan/Denizli genotiplerinin yağ oranları en yüksek değerler içerisinde yer almıștır.

\section{Sonuç}

Tokat-Kazova șartlarında 20 genotiple yürütülen bu çalıșmada Aybak-2013-13DAÇ130100 (529kg/da), Baklan/Denizli (573 kg/da), Karakeçili/Kırıkkale (538kg/ da) ve İnegöl Alası (545 kg/da) genotipleri tohum verimi bakımından ilk sıralarda yer almıștır. Baklan/Denizli çerezlik ayçiçeği popülasyonunun en yüksek tohum verimine sahip olduğu belirlenmiștir. Ayrıca bu genotip, tabla çapı, tablada tane sayısı, tane eni, tane boyu ve tohum verimi bakımından istatistiki olarak ilk grupta yer almıștır. Yapılan araștırmada Baklan/Denizli popülasyonunun tüm özellikleri bakımından elverișli olmasından dolayı Tokat-Kazova șartlarında yetiștiriciliğinin yapılabileceği sonucuna varılmıștır.

\section{Kaynaklar}

Akkaya i.,, 2006. Çerezlik Ayçiçeği Çeșitlerinde (Helianthus annuus L.) Ekim Zamanı ve Bitki Sıklığının Verim ve Kalite Özellikleri Üzerine Etkisi. Yüksek Lisans Tezi, Uludağ Üniversitesi, Fen Bilimleri Enstitüsü, Tarla Bitkileri Anabilim Dalı, Doktora Tezi, Bursa

Anonim, 2014a. http://www.tuik.gov.tr (Erișim tarihi: 25.05.2017)

Anonim, 2014b. Tarımsal Değerleri Ölçme Denemeleri (TDÖ) Teknik Talimatı, Tohum Tescil ve Sertifikasyon Genel Müdürlüğü

Çil A., Çil A.N., Evci G., Kıllı F., 2011. Bazı yağlı ayçiçeği (Helianthus annuus L.) Hibridlerinin çukurova koșullarında bitkisel ve tarımsal özelliklerinin belirlenmesi. IX. Tarla Bitkileri Kongresi, Cilt: 2, s. 996-999. Bursa

Day S., 2011. Ankara Koșullarında Yerli ve Hibrit Çerezlik Ayçiçeği (Helianthus annuus L.) Genotiplerinde Farklı Sıra Üzeri Aralıkları ve Azot Dozlarının Verim ve Verim Ögelerine Etkisi. Doktora Tezi, Ankara Üniversitesi Fen Bilimleri Enstitüsü, $89 \mathrm{~s}$. Ankara

Düzgüneș O., Kesici T., Kavuncu O. ve Gürbüz F., 1987. Araștırma ve Deneme Metotları (İstatistik Metotları II). Ankara Üniversitesi Ziraat Fakültesi Yayınları: 1021, 295 s. Ankara

Ekin Z., 2005. Van'da Yağlık Ayçiçeği (Helianthus annuus L.) Çeșitlerinde Farklı Ekim Zamanı ve Bitki Sıklıklarının Tarımsal, Fizyolojik, Verim ve Kalite Özellikleri Üzerine Etkileri. Yüzüncü Yıl Üniversitesi Ziraat Fakültesi Tarla Bitkileri Ana Bilim Dalı. Basılmamıș Doktora Tezi. 166 s. Van 
Fick G.N., Zimmer D.E., Dominguez-Gimenez J., and Rehder R.A., 1974. Fertility restoration and variability for plant and seed characteristics in wild sunflowers. In: Proceedings of the 6th International Sunflower Conference, Bucharest, Romania, pp. 333-338

Fick G.N., 1978. Sunflower breeding and genetics. In: Carter JF (ed) Sunflower science and technology. ASA, CSSA and SSSA, Madison, pp. 279-327

Gundaev A.I., 1971. Basic Principles of Sunflower Selection. Genetic Principles of Plant Selection, Nauka, Moscow. 1971. pp. 417-465 (Transl. Department of the Secretary of State, Ottawa, Canada, 1972)

Karaman M.R. ve Brohi A., 2004. Toprakta Bulunan Bitki Besinlerinin Yöntemlere Göre Sınır Değerleri. Tarım Sanayi Çevre Bildiri Kitabı, Ek Tablolar Bölümü, Nobel Yayıncılık, s. 14151426, Ankara

Karadoğan T. ve Özgödek Z., 1994. Çerezlik karakterdeki bazı ayçiçeği ekotiplerinin verim ve verim unsurları üzerine bir araștırma. Atatürk Üniversitesi Ziraat Fakültesi Dergisi 25(2), s.188201, Erzurum

Karakaș M., 2012. Kıraç ve Taban Arazi Koșullarında Yağlık Ayçiçeği (Helanthus annuus L.) Çeșitlerinin Verim ve Kalite Kriterlerinin Belirlenmesi. Yüksek Lisans Tezi. Ondokuz Mayıs Üniversitesi, Fen Bilimleri Enstitüsü, Samsun

Kaya Y., 2004. Confectionery sunflower production in Turkey. Proceeding of 16th International Sunflower Conference. August 29-September 2. pp. 817-822, Fargo, USA

Kaya Y., Evci G., Sezgin D., Pekcan V. Gücer T. ve Durak S., 2006. Farklı çevre koșullarında ayçiçeğinde (Helianthus annuus L.) tane verimi ve diğer verim öğeleri arasında ilișkilerin belirlenmesi. Trakya Üniversitesi Fen Bilimleri Dergisi. 7(1): s. 37-44

Katar D., Bayramin S., Kayaçetin F. ve Arslan Y., 2012. Ankara ekolojik koșullarında farklı ayçiçeği (Helianthus annuus L.) çeșitlerinin verim performanslarının belirlenmesi. Ankara Tarım Bilimleri Dergisi, 27(3), s.140-143

Knowles P.F., 1978. Morphology and anatomy. In: J.F. Carter (Ed.), Sunflower Science and Technology. Agronomy Monograph 19, ASACSSA-SSSA. Madison. WI, USA, pp. 55-87
Lofgren J.R., 1978. Sunflower for confectionery food, birdfood and pet food. In: J. F. Carter Sunflower Technology and Production ASA, SCA and SSSA Monograph, 19 Madison WI. pp. 441-456

Majid H.R., and Schnettier A.A., 1988. Yield and quality of semi-dwarf and standard height sunflower hybrids grown and five plant populations. Agronomy Journal, v. 79, pp. 681684

Özgödek Z., 1993. Erzurum ekolojik șartlarında yetiștirilen bazı çerezlik ayçiçeği ekotiplerinin adaptasyonu ve bazı önemli tarımsal özelliklerinin incelenmesi. Atatürk Üniversitesi, Fen Bilimleri Enstititüsü, Yüksek lisans Tezi, $49 \mathrm{~s}$

Pathak R.S., 1974. Yield Components in sunflower. Proceedings of the 6th International Sunflower Conference, Bucharest, Romania, pp. 271-281

Polatı O., 2013. Çerezlik Ayçiçeği (Helianthus annuus L.) Populasyonlarında Dane Özellikleri ve Özellikler Arası İlișkiler. Yüksek Lisans Tezi, Adnan Menderes Üniversitesi, Fen Bilimleri Enstitüsü, Aydın

Öztürk Ö., Akınerdem F., Bayraktar N. ve Ada R., 2008. Konya sulu koșullarında bazı hibrit ayçiçeği çeșitlerinin verim ve önemli tarımsal özelliklerini belirlenmesi. Selçuk Üniversitesi Ziraat Fakültesi Dergisi, 22 (45), s.11-20

Shabana R., 1975. Genetic variability of sunflower varieties and inbred lines. In: Proceedings of the 6th International Sunflower Conference, July 22-24, 1974, Bucharest, Romania, Genetics pp. 263-269

Turan Z.M. ve Göksoy A.T., 1998. Yağ Bitkileri. Uludağ Üniversitesi, Ziraat Fakültesi Ders Notları, 80. s. 225, Bursa

Tursun A.Ö., 2011. Kahramanmaraș Kuru Koșullarında Farklı Ekim Düzenlemeleri ve Azot Uygulamalarının Yağlık Ayçiçeğinde Verim, Verim Unsurları ve Bazı Fizyolojik Özelliklere Etkisi. Doktora Tezi. Kahramanmaraș Sütçü İmam Üniversitesi, Fen Bilimleri Enstitüsü, 140 s, Kahramanmaraș

Zubillaga M.M., Aristi J.P., and Lavado R.S., 2002. Effect of phosphorus and nitrogen fertilization on sunflower (Helianthus annus L.) nitrogen uptake and yield. Journal Agronomy \& Crop Science, Vol. 188, pp. 267-274 